Alma Mater Studiorum - Università di Bologna DEPARTMENT OF ECONOMICS

Small, young, and exporters: New evidence on the determinants of firm growth

Marco Grazzi

Daniele Moschella

Quaderni - Working Paper DSE $N^{\circ} 1068$

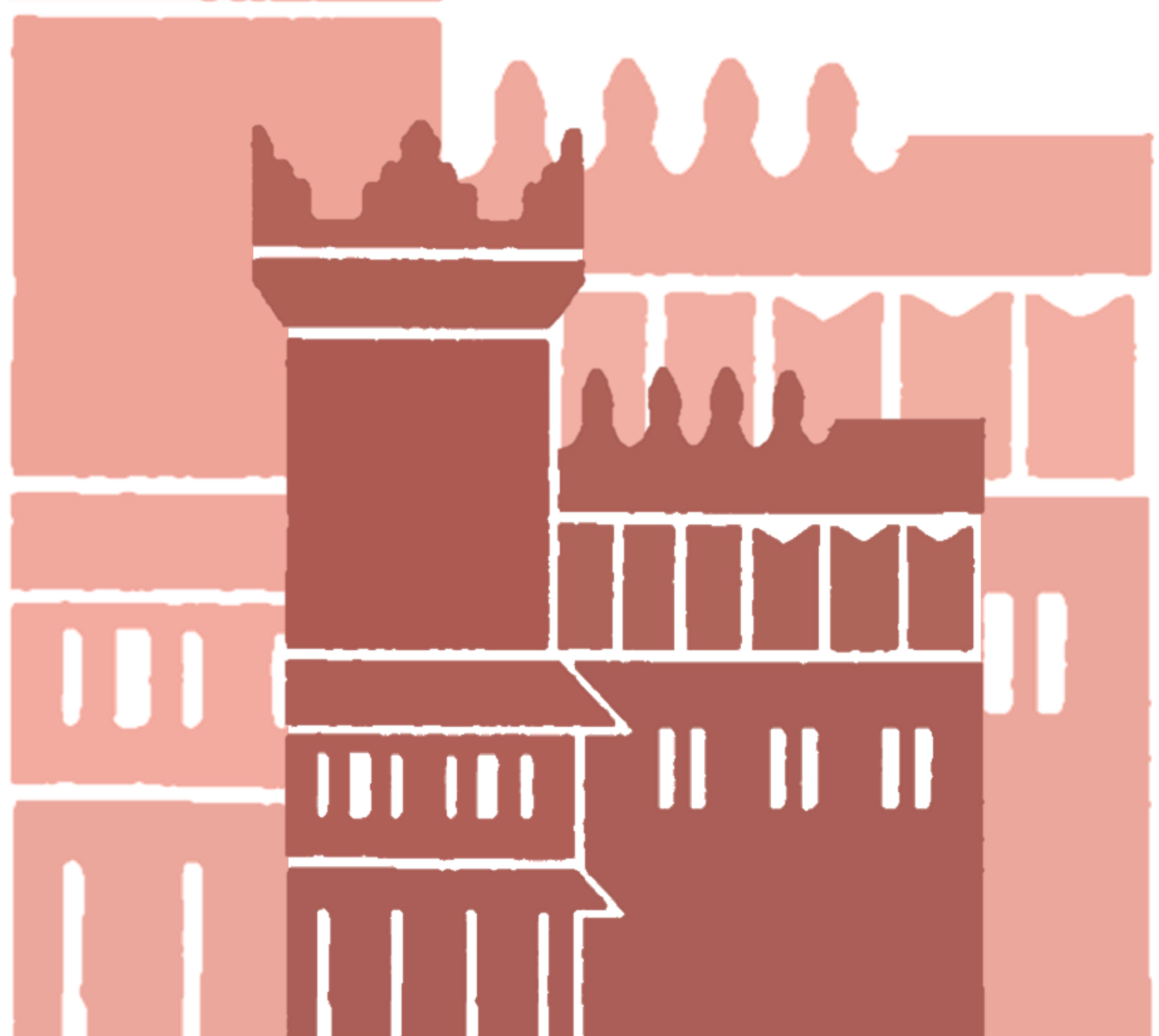




\title{
SMALL, YOUNG, AND EXPORTERS: NEW EVIDENCE ON THE DETERMINANTS OF FIRM GROWTH* $^{*}$
}

\author{
Marco Grazzi ${ }^{\dagger}$ \\ Department of Economics, University of Bologna \\ Daniele Moschella \\ Institute of Economics, Scuola Superiore Sant'Anna
}

June 7, 2016

\begin{abstract}
This work investigates how the export status of the firm influences the patterns of growth at different age classes. We address this research question resorting to a novel set of data that links together the universe of Italian firms and detailed data on export transactions. We find that the positive relationship between export status and growth declines with firm age. Further, we also find that, even when accounting for the role of age, the negative size-growth relationship does not disappear, contrary to some recent evidence. These results, which are robust to a series of controls, suggest for a positive signaling role of the export status which is stronger for young exporters or born globals. Exploiting the product-country level dimension of the customs data we also provide, for the first time, evidence on differences in exchange rates pass through between young and experienced exporters. In particular, we find that early exporters appear to be well equipped to face exchange rates variations as their exports decrease less following a currency appreciation.

Keywords: Firm age and performance, Firm growth, International trade, Born global, Exchange rates pass through
\end{abstract}

JEL classification: D22, F14, L11, L21, L25

${ }^{*}$ We thank two anonymous referees for useful remarks. For helpful comments on earlier drafts, we also thank Giulio Bottazzi, Werner Holzl, Valentina Meliciani, Massimo Molinari, Hiroyuki Okamuro, Federico Tamagni, and participants at the conference Governance of a Complex World, Turin, in June 2014, at the Druid conference, Rome, June 2015, and at Brunel University seminar, in October 2015. Marco Grazzi gratefully acknowledges Fondazione Cassa dei Risparmi di Forlì, Grant ORGANIMPRE, for financial support. Daniele Moschella greatly acknowledges the financial support of the Italian Ministry of Education, University, and Research (SIR Programme, project number RBSI14JAFW). This article was completed within the ISIGrowth project funded by the European Commission under the Horizon 2020 Framework Programme. Without the unique support of the Italian Statistical Office, and in particular Roberto Monducci, this all endeavour would not have been possible. The usual disclaimer applies.

${ }^{\dagger}$ Piazza Scaravilli 2, 40126 Bologna, Italy. tel: +39 0512098130, email: marco.grazzi@unibo.it

$\ddagger$ Corresponding author. Piazza Martiri della Libertà 33, 56127 Pisa, Italy, tel: +39 050883343 , email: d.moschella@sssup.it 


\section{Introduction}

This work investigates the role of firm age in explaining the different patterns of firms' growth. More in detail, we study how the export status of the firm influences the patterns of growth at different age classes. The results show that the positive effect associated to the export status declines with firm age. Further, we also find that contrary to recent evidence on US (Haltiwanger et al., 2013) the negative size-growth relationship does not vanish even when accounting for the role of age. These results, which are robust to a series of controls, suggest a signaling role of the export status which is stronger for young exporters or born globals. On the one hand, the administrative source of the data that we employ enables us to perform the analysis on the universe of Italian firms and hence, also to properly account for firm entry and exit. We of course acknowledge, on the other hand, that the almost complete lack of any qualitative evidence in administrative sources does not allow us to speculate much on the implication of our findings. However, we make the most of the available set of data and by resorting to detailed transaction level data we provide some more insights on the role and characteristics of born globals that could be further investigated in future works. In particular, we find that early exporters appear to be well equipped to face exchange rates variations as their exports decrease less following a currency appreciation.

Our work mostly contributes to two related fields of literature. First, it builds upon the literature studying the role of firms in international trade (see, among the many others Melitz, 2003; Bernard et al., 2007; Melitz and Ottaviano, 2008). Some of the works resorting to the recently available firm (or transaction) level data have also started to investigate the role of age reporting rather contrasting evidence. Roberts and Tybout (1997), for instance, employ the Colombian Census data, covering plants bigger than 10 employees, to investigate how age affects both the probability of exporting and the profitability of sales abroad. The authors report a positive effect of age on both export propensity and performance. Arnold and Hussinger (2005) investigate the probability of being an exporter for a sample of German firms over the period 1992-2000 and they report opposite findings: younger firms are more likely to export. More recently, Berthou and Vicard (2015) employ French customs data over the period 1994-2008 and show that, among exporting firms, younger companies display higher net growth rates of exports. ${ }^{1}$ Our contribution to this stream of literature is twofold. On the one hand, we can resort to the universe of Italian companies to investigate how the growth performance of exporting vis à vis non exporting firms changes over all the age spectrum. Further, we also investigate how the age and the size of the firm jointly contribute to shape the different patterns of firms growth. On the other hand, exploiting the transaction level dimension of the customs data we are the first to provide evidence of the different performance of young exporting firms within a product-country pair, thus also providing results on differences in exchange rates pass through (ERPT) between young and experienced exporters.

A second stream of literature to which this work contributes is the more traditional one on firm growth. In this respect, at least since the work of Birch (1981), small firms have been considered, especially by policy makers, as a relevant source of job creation. The hypothesis according to which smaller firms grow more than bigger ones would represent an apparent violation of the Gibrat's law (see among the others Sutton, 1997;

\footnotetext{
${ }^{1}$ There also exists a previous work that employ the age variable to investigate differences between exporters and domestic firms in Italy. However, Castellani and Zanfei (2007) only employ age only as a control variable and do not report its coefficient.
} 
Lotti et al., 2003; Coad, 2009). The increasing availability of firm level dataset has further fostered research on the topic, see, among the many others, Davis and Haltiwanger (1992) and Davis et al. (1996). These first works, in addition to providing a methodological benchmark for future studies, confirmed that smaller firms were major players in terms of job churning, hence contributing both to employment creation and destruction. Now, more recent contributions, that also look at the age of the firm, challenge that evidence. ${ }^{2}$ In particular, Haltiwanger et al. (2013), using data from the Census Bureau's Longitudinal Business Database (LBD), show that the negative relationship between firm size and growth disappears and may even reverse sign among the biggest firms. This evidence casts doubt on policy interventions aimed at small businesses but ignoring the role of firm age. Along similar lines, Lawless (2014), using survey data on Irish firms, show that once accounting for firm age the inverse relationship between growth and size declines very markedly across different age categories. The present paper contributes to this stream of literature by showing that the export status is a crucial dimension to understand firm growth patterns together with firm age and size.

Our findings of different effects of export status at different age groups also contribute to that stream of literatures which, within industrial economics, studies how firm heterogeneity - and in particular productivity differences - are related to growth, at the level of the firm, and to reallocation of market shares, at the level of the industry. In this respect, the recent economic slowdown and its consequences further complicated the task of the applied economist and of the policy maker seeking to identify the determinants of firm growth and the role of distinct categories of firms in contributing to aggregate growth. In most industrialized countries, over the last five years the growth rate of GDP per capita has been close to zero, if not negative (Fig. 1.1 from OECD, 2012). In such a scenario, also the most standard and reliable predictors of firm performance, such as productivity or export status, did not regularly allow to discriminate between high and low growth firms. Rather unexpectedly, higher than industry average productivity does not appear to automatically translate into higher firm growth (for evidence on both Europe and US see Bottazzi et al., 2010; Dosi et al., 2012, 2015b). The fact that productivity is not systematically related to firm growth suggests that such pure efficiency measure might not adequately capture the willingness to take up new business opportunities. In this respect, the setting up of a new firm which exports since its very inception may well signal both the existence of the skills and capabilities required to engage in international trade $^{3}$ and, at least as relevant, the willingness to look for growth opportunities not only domestically, but also abroad. The lack of more qualitative data about entrepreneurs' and managers' characteristics and motivations do not allow to investigate such behavioral hypothesis of firm growth in greater detail. However, we notice that our results on the superior growth performance of young exporters are very much consistent with the "willingness to growth" conjecture. Using two concepts from the entrepreneurship literature, we may say that "born-global" firms (Knight and Cavusgil, 2004) display a "willingness to growth" (Davidsson, 1989), which, ceteris paribus, allow them to better perform in

\footnotetext{
${ }^{2}$ Evans (1987b,a) provided an early attempt to look at the effect of age on the size-growth relationship. The author, employing firm-level data for U.S. manufacturing firms, reported an inverse relationship between firm growth and size (holding firm age constant) and between firm growth and age (holding firm size constant). However, as noted by Evans, the available data underrepresented smaller firms.

${ }^{3}$ As noted by one of the referee, given the limited set of variables available, we cannot directly measure firms' productivity. However, we rely here on the very strong empirical regularity according to which exporting firms are more productive than domestic-only ones (see, among the many others Bernard et al., 2007; International Study Group on Exports and Productivity, 2008).
} 
Table 1: Observations by year and export status

\begin{tabular}{ccccc}
\hline Year & All firms & Non exporters & Exporters & Exporters $(\%)$ \\
\hline 2000 & $4,215,837$ & $4,079,190$ & 136,647 & 3.24 \\
2001 & $4,297,248$ & $4,155,779$ & 141,469 & 3.29 \\
2002 & $4,317,543$ & $4,172,142$ & 145,401 & 3.37 \\
2003 & $4,321,519$ & $4,178,187$ & 143,332 & 3.32 \\
2004 & $4,361,695$ & $4,222,155$ & 139,540 & 3.20 \\
2005 & $4,452,859$ & $4,319,444$ & 133,415 & 2.00 \\
2006 & $4,479,640$ & $4,340,335$ & 139,305 & 3.11 \\
\hline
\end{tabular}

Note. All firms. Exporters are defined as firms with strictly positive exports.

terms of growth rate with respect to other firms.

In concluding, the age profile of the firm emerges as yet another characteristic that contributes to account for the relevant and persistent degree of heterogeneity that one observes across firms (see the discussion and the methodology proposed in Dosi et al., forthcoming).

The remaining of the paper is organized as follows. Section 2 describes the data. Section 3 provides a first account of the age-size profile and the growth patterns of firms, also employing non-parametric analysis of growth rate distributions of exporting and non exporting firms. Section 4 presents the results of the regression analysis. Section 5 concludes.

\section{Data}

The analysis is based upon two firm-level datasets collected by the Italian statistical office (ISTAT), namely the Business Register known as "Archivio Statistico Imprese Attive" (ASIA) and Statistiche del Commercio Estero (COE). ASIA is the register of all active Italian businesses. It covers the period 1998-2006 and contains information on firms' operations including the total number of people working in the firm, the number of employees, total turnover, ${ }^{4}$ geographic location of the firm, and firm's age, defined as the first year in which the firm appears in any of the register monitored by the Statistical Office. The COE dataset consists of all cross-border transactions performed by Italian firms and it covers the period 2000-2007 on an annual basis. The data can be disaggregated at the level of the triplet firm-product-country, meaning that it is possible to know the value of export of each firm in each product-country destination in which it is active. ${ }^{5}$ Further, since COE includes both the value and the quantity of export, it is possible to compute the unit values of transaction within each product-country pair. Using the unique identification code of the firm, we link the firm-level export data from COE to ISTAT's archive of active firms. The data collection and building process of the integrated database are described at length in Grazzi et al. (2013).

Notice that the resulting dataset is not a sample but rather it covers the universe of Italian active firms and all their export transactions over the period 2000-2006. In the reminder of the paper a firm is defined as a legal entity which is registered in ASIA in a

\footnotetext{
${ }^{4}$ Information on total turnover is available only in 2000 and 2003.

${ }^{5} \mathrm{~A}$ product is defined as a six digit category in the Harmonized System (HS6).
} 
given year. ${ }^{6}$ This definition includes both employer and nonemployer firms. ${ }^{7}$

Table 1 reports the breakdown of our dataset (30,446,341 observations in total) by years and export status. The number of active businesses slightly increases over time, whereas the number of exporters, both in absolute term and as percentage of the total, appears to fluctuate during the period. Export participation over the universe of firms is rather low, around $3 \%$ in 2000, which is somewhat lower than in most other countries for which evidence is available (an in depth comparative analysis is performed in a collective effort by the International Study Group on Exports and Productivity, 2008). The reason is twofold. First, data from Structural Business Statistics are usually available only for firms above a certain size threshold. Given the known positive relationship between size and export status, left truncation of the size distribution provides an overestimation of the percentage of exporting firms. This is the case, for instance, of the dataset employed in Serti and Tomasi (2008) and Grazzi (2012) which report a rather high export participation (around 70\% for manufacturing firms) for firms bigger than 20 employees. Second, and related, the firm size distribution of Italian business companies is even more left skewed than that of other countries, hence left truncation causes a bigger bias than for countries with a less skewed distribution of firm size.

Although we can resort to the universe of Italian firms and of their transactions with counterparts abroad there still exists a potential limitation concerning the export data as they only cover the so called "direct exports". By way of illustration, if a small manufacturing firm cannot cover the sunk cost related to direct exporting, it might decide to sell domestically the good to another firm which will act as intermediary and will take care of exporting the good (see among the others Bernard et al., 2010; Ahn et al., 2011; Bernard et al., 2015). Since customs register transactions only when goods cross borders, only the latter firm will show up in the trade date. No record is kept of the smaller manufacturing firms which de facto is an indirect export. Although we cannot report explicit evidence about the relevance of indirect exporting in Italy, data on a wide set of countries from the World Bank Business Environment and Enterprise Performance Survey (BEEPS) document that, on average, the ability to export indirectly (i.e. through export intermediaries) increases by one third the number of firms that can reach foreign markets with their goods (Grazzi and Tomasi, 2016). Given the disproportionate presence of small firms in the Italian economy (see more below) it is reasonable to expect that many small domestic manufacturers would resort to intermediaries to access to foreign destinations. In this sense, by taking into account only direct exports, we are possibly underestimating the export activity of small firms. We also neglect trade in services as we lack data on this dimension. ${ }^{8}$

In this work, we are mainly interested in how age, size, and export status interact in explaining the different patterns of firms growth. Age is measured as the number of years

\footnotetext{
${ }^{6}$ Note that we cannot keep track of firm undergoing events such as mergers or acquisitions. Hence if the merger between two firms gives rise to a new legal entity, this event is registered as a firm entry. Similarly, a firm which is acquired would correspond to an exit.

${ }^{7}$ We use the distinction of the U.S. Census Bureau, according to which nonemployers are business units without paid employees. For firm-level analysis of employment dynamics including both employer and nonemployer firms see Davis et al. (2009); Neumark et al. (2011), whether Haltiwanger et al. (2013) use only employer firms. Notice that we use here the same set of export data as those employed in Bernard et al. (2015).

${ }^{8}$ This, however, should not result in an appreciable underestimation of export activity. Ariu (forthcoming), using Belgian data, shows that trade in services is very rare; in manufacturing sectors, less than $1 \%$ of firms do export services.
} 
Table 2: Observations by sector of economic activity in year 2000

\begin{tabular}{|c|c|c|c|c|c|c|c|c|c|c|}
\hline \multirow[t]{2}{*}{ Sector } & \multicolumn{5}{|c|}{ All firms } & \multicolumn{5}{|c|}{$>20$ employees } \\
\hline & (I) & (II) & (III) & (IV) & $(\mathrm{V})$ & (I) & (II) & (III) & (IV) & (V) \\
\hline Manufacturing & 567,633 & 13.46 & 31.25 & 13.83 & 85.12 & 35,953 & 51.46 & 44.70 & 68.31 & 92.21 \\
\hline Energy & 6,280 & 0.15 & 0.75 & 5.91 & 0.14 & 617 & 0.88 & 1.44 & 20.42 & 0.14 \\
\hline Construction & 520,840 & 12.35 & 9.74 & 0.49 & 0.26 & 5,775 & 8.27 & 4.44 & 07.96 & 0.22 \\
\hline Wholesale trade & 488,225 & 11.58 & 8.29 & 7.38 & 9.74 & 5,595 & 8.01 & 4.86 & 64.99 & 4.52 \\
\hline Retail trade & 725,914 & 17.22 & 10.52 & 1.44 & 0.74 & 3,000 & 4.29 & 5.26 & 27.17 & 0.50 \\
\hline Transport \& TLC & 166,714 & 3.95 & 7.72 & 1.08 & 1.20 & 4,194 & 6.00 & 13.19 & 11.47 & 1.29 \\
\hline Financial & 896,507 & 21.27 & 17.02 & 0.51 & 2.67 & 7,932 & 11.35 & 17.61 & 07.37 & 1.04 \\
\hline Other services & 843,724 & 20.01 & 14.69 & 0.28 & 0.13 & 6,805 & 9.74 & 8.49 & 03.95 & 0.08 \\
\hline Total & $4,215,837$ & 100 & 100 & & 100 & 69,871 & 100.00 & 100 & & 100 \\
\hline
\end{tabular}

Note. (I) Number of firms; (II) distribution of number of firms (\%); (III) distribution of employment (\%); (IV) percentage of exporting firms within each sector (\%); (V) distribution of export volumes (\%).

since the firm first appeared in any of the different (administrative, statistical, fiscal, etc.) registers. Size is measured as the number of people actually working in the firm, we indeed consider both employer and nonemployer firms. This is our preferred measure of size as total sales are available only in two non-consecutive years (2000 and 2003). Total exports, another potential measure of firm size, is also not adequate, as it excludes non exporting firms, the vast majority in our sample. As a result the measure of growth that we employ throughout the paper is the variation, on annual basis, of the number of people working in a firm. Such measure also facilitates the comparison of our findings with those of the related literature analyzing the role of age and size in job creation (see, among the many others Haltiwanger et al., 2013; Lawless, 2014).

Table 2 reports the distribution of firms across economic activities and it also shows that imposing a size threshold has a relevant impact on the distribution of firms across sectors of economic activity. When accounting for the universe of firms, the manufacturing sectors account for less than $15 \%$ of the total number of firms; the most numerous sectors in terms of firms are Retail trade, Financial service, and Other services, which include bars, restaurants and hotels. On the contrary, when imposing the 20 employees threshold, a standard cutoff on many firm level datasets, one recovers the disproportionate share of manufacturing firms that we are accustomed to observe. Given the wide variation in the organization of business across sectors of economic activity, in the remainder of the paper we focus only on firms in the manufacturing sectors. Manufacturing firms - as expected - also account for the largest share of exports of goods. ${ }^{9}$

\section{Export participation and the age-size profile}

The relation between firm size and export propensity has been much investigated in the literature, and the empirical consensus of a positive relationship (Wagner, 2001; Bernard et al., 2007) is well accounted by existing theories of sunk costs for export market participation (Melitz, 2003). On the contrary, the positive role of firm age in explaining firm propensity to export has received a less clear-cut support from the empirical evidence (Roberts and Tybout, 1997; Arnold and Hussinger, 2005). In this section, we provide evidence on the subject exploiting the universe of Italian manufacturing firms.

In Table 3 we take advantage of information on both size and age to provide, for the

\footnotetext{
${ }^{9}$ For a comparative analysis of the role of manufacturers, vis-à-vis wholesalers, refer to Bernard et al. (2015).
} 
Table 3: Distribution of firms by age, size class, and export status in 2000

\begin{tabular}{|c|c|c|c|c|c|}
\hline \multirow[b]{2}{*}{ Age Class } & \multicolumn{4}{|c|}{ Size class } & \multirow[b]{2}{*}{ All } \\
\hline & 1 & $2-9$ & $10-19$ & $20+$ & \\
\hline \multirow[t]{4}{*}{ Age $<5$} & 81,396 & 64,999 & 8,159 & 4,057 & 158,611 \\
\hline & 13.41 & 10.71 & 1.34 & 0.67 & 26.13 \\
\hline & 3.35 & 9.67 & 26.07 & 47.47 & 8.24 \\
\hline & 1.64 & 4.72 & 2.18 & 5.06 & 13.61 \\
\hline \multirow[t]{4}{*}{ Age 5-10 } & 54,352 & 59,627 & 10,896 & 5,979 & 130,854 \\
\hline & 8.95 & 9.82 & 1.80 & 0.98 & 21.56 \\
\hline & 3.29 & 11.72 & 32.51 & 56.83 & 12.01 \\
\hline & 1.10 & 4.65 & 2.95 & 6.85 & 15.54 \\
\hline \multirow[t]{4}{*}{ Age $11-20$} & 55,497 & 77,326 & 18,064 & 11,164 & 162,051 \\
\hline & 9.14 & 12.74 & 2.98 & 1.84 & 26.70 \\
\hline & 2.85 & 10.73 & 34.52 & 63.18 & 14.30 \\
\hline & 1.12 & 6.19 & 4.95 & 11.26 & 23.52 \\
\hline \multirow[t]{4}{*}{ Age $21+$} & 44,194 & 73,793 & 19,184 & 18,326 & 155,497 \\
\hline & 7.28 & 12.16 & 3.16 & 3.02 & 25.62 \\
\hline & 2.63 & 10.63 & 37.83 & 75.53 & 19.36 \\
\hline & 0.89 & 6.04 & 5.26 & 35.14 & 47.32 \\
\hline \multirow[t]{4}{*}{ All } & 235,439 & 275,745 & 56,303 & 39,526 & 607,013 \\
\hline & 38.79 & 45.43 & 9.28 & 6.51 & 100.00 \\
\hline & 3.08 & 10.67 & 34.03 & 66.33 & 13.52 \\
\hline & 4.76 & 21.60 & 15.34 & 58.31 & 100.00 \\
\hline
\end{tabular}

Note. Each cell reports, top to bottom, the number of firms, the percentage over the total (\%), the percentage of exporting firms in that cell (\%), the share of employment $(\%)$.

year 2000, a complete descriptive account of the joint distribution of the variables we are mostly interested in: age, size and export status. In order to do so, we divide firms in four size classes: class 1 contains firms with employees $\geq 1$ and $<2$; class $2-9$ contains firms with employees $\geq 2$ and $\leq 9$; class $10-19$ contains firms with employees $>9$ and $\leq 19$; class $20+$ contains firms with employees $>19$. Such classification of firms across size classes is borrowed from Haltiwanger et al. (2013) and then adapted to the peculiarity of the Italian context by grouping together firms bigger than 20 employees which are rather few in absolute numbers $(39,526)$, representing only the $6.51 \%$ of the population. Similarly, we assigns firms to four age classes, respectively, less than five years from birth, between 5 and 10, between 10 and 20, and more than 20 years from foundation. In the expanding literature on the role of firm age, such classification is employed, among the others, also by Lawless (2014).

Each cell of Table 3 reports the number of firms, the percentage over the total, and the percentage of exporting firms within the cell. The first two size classes account for more than $84 \%$ of all firms, but they contain relatively few exporters: export propensity is around $3 \%$ in the first size class, and around $11 \%$ in the second class. The ratio of exporters over nonexporters increases dramatically among firms in the last two size classes, which contain less than $20 \%$ of all firms, but with an export propensity which goes from around $34 \%$ in the class $10-19$, to around $66 \%$ in the class $20+$. Finally, as 

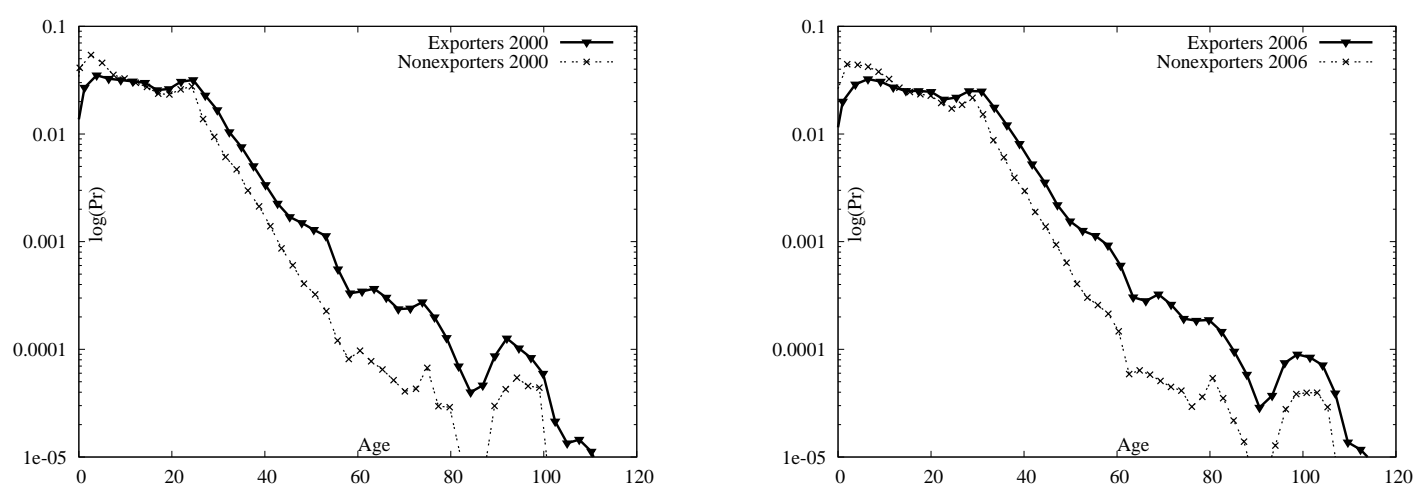

Figure 1: Kernel density of the age distribution for exporters and nonexporters, in 2000 and 2006. Kernel densities are computed using an Epanechnikov kernel

could be easily expected, even though the distribution of firms is much concentrated in the two classes of smaller size, the largest share of employment (58.31\%) is accounted for the firms bigger than 20 employees.

As for age, start by noting that the universe of firms is rather evenly distributed across age classes (with the exception of the class 5-10, which contains a smaller percentage of firms) and the same occurs for non exporting firms (not reported in the table). On the contrary, exporters are more concentrated in the category of firms with more than 20 years, as more than one third of exporters belong to such class (not reported in the table). The export propensity is increasing across age categories, going from $8.24 \%$ of the first class to $19.36 \%$ of the last class. Overall, one notices that if being an exporter is already an exception with respect to the universe of manufacturing firms, being a young exporter is even a much rarer event. Looking both across age and size dimensions, we notice that in the first two size classes, export propensity does not change much with age. On the contrary, in the last two size classes, export propensity is markedly increasing in age; in the last size class, it goes from around $47 \%$ among young firms (age $<5$ ), to around $75 \%$ among old firms (age 21+).

The relation between firm age and export status is also shown in Figure 1 by means of kernel density estimation for the years 2000 and 2006. The linear decay in the distributions over most of their support suggests that an exponential law would be an acceptable representation of empirical distributions, with departures from the linear fit among the youngest and the oldest firms, in line with the evidence emerging from other studies (Coad, 2010; Coad and Tamvada, 2012; Barba Navaretti et al., 2014). In particular, notice that the modal age among non exporters is 2 years in 2000, whereas it is 24 years among exporters: this implies that the departure from the exponential benchmark is negligible in the case of nonexporting young firms, while it is quite pronounced in the case of young exporting firms. ${ }^{10}$ Finally, Figure 1 shows that the age distributions is almost unchanged over time.

Somewhat surprising, age has only a limited impact on the persistency of the export status, as shown by Table 4, which reports the annual transition matrix in and out of exporting for each age class. The probability to export in $t+1$, given that a firm was already exporting in the previous year, is around $79 \%$ in the first age class, and is only mildly increasing throughout the four classes. In general, the observed persistency in

\footnotetext{
${ }^{10}$ An exponential distribution would predict a modal age equal to the very youngest age group (Coad, 2010, p. 10).
} 
Table 4: Transition matrix in and out of exporting

\begin{tabular}{|c|c|c|c|c|c|c|c|c|}
\hline & \multicolumn{2}{|c|}{ Age $<5$} & \multicolumn{2}{|c|}{ Age 5-10 } & \multicolumn{2}{|c|}{ Age 11-20 } & \multicolumn{2}{|c|}{ Age $21+$} \\
\hline & 0 & 1 & 0 & 1 & 0 & 1 & 0 & 1 \\
\hline 0 & 96.80 & 3.20 & 97.33 & 2.67 & 97.30 & 2.70 & 96.95 & 3.05 \\
\hline 1 & 21.03 & 78.97 & 19.96 & 80.04 & 17.12 & 82.88 & 13.79 & 86.21 \\
\hline
\end{tabular}

Note. 0 and 1 represent the status of nonexporter and exporter.

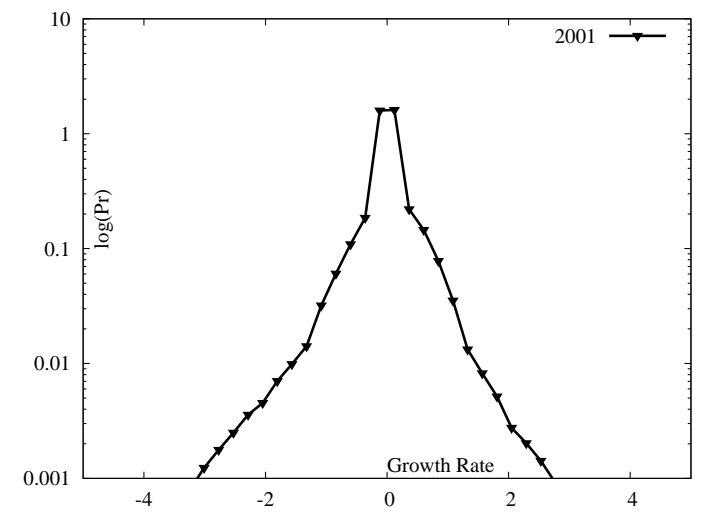

(a) Growth rates Distribution, 2001

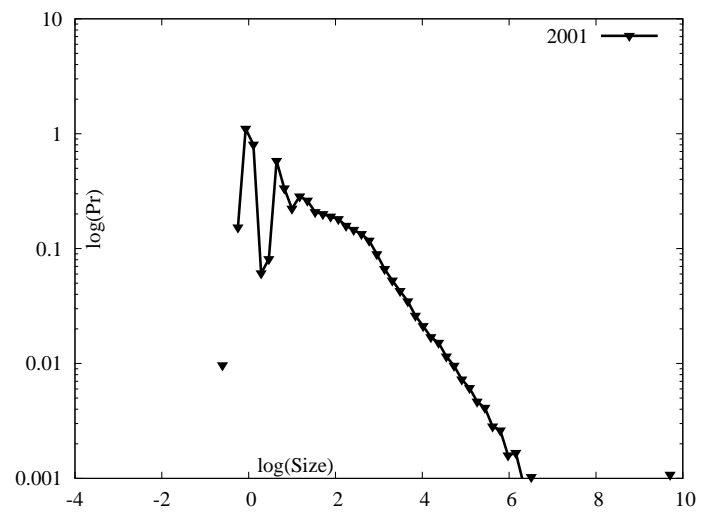

(b) Size distribution, 2001

Figure 2: Kernel density estimation of growth rates and firm size.

export status is quite high, in agreement with the available evidence from other countries (see Roberts and Tybout, 1997 for data on Colombia, Bernard and Jensen, 2004 for U.S. and Grazzi, 2012 for sample of medium and large Italian firms). Both the high persistency and the low entry rate into export markets (first row of Table 4) provide supporting evidence to the sunk costs hypothesis (Melitz, 2003) for engaging into international trade. In particular, the high persistency in the export status displayed in Table 4 shows that the explanation of exporting behaviour based on sunk costs is robust to age disaggregation.

\subsection{Growth rates}

In order to study the pattern of growth of the different categories of firms (i.e. with respect to size, age and export status) we focus on the yearly growth rates of employment, as such variable is available for each year. In line with most of the previous literature, the growth rate is computed as the log-difference between two consecutive years:

$$
g_{i, t}=\ln S i z e_{i, t}-\ln S i z e_{i, t-1}
$$

Figure 2 (left) presents the distribution of growth rates for all firms in 2001, together with the size distribution (right) in the same year. Notice again that this is the universe, and not the sample of Italian firms. The growth rates distribution displays the familiar "tentshape" which has been found in several datasets (see, among others, Stanley et al., 1996; Bottazzi and Secchi, 2006; Coad, 2007; Bottazzi et al., 2011) confirming the existence of a large share of 'lumpy' growth events, of both positive and negative sign. This work also presents for the first time the size distribution of the whole population (i.e. no left truncation) of Italian manufacturing firms. The right tail of the distribution is quite close to the Pareto benchmark, i.e. a straight line of negative slope on log-log axes (Axtell, 


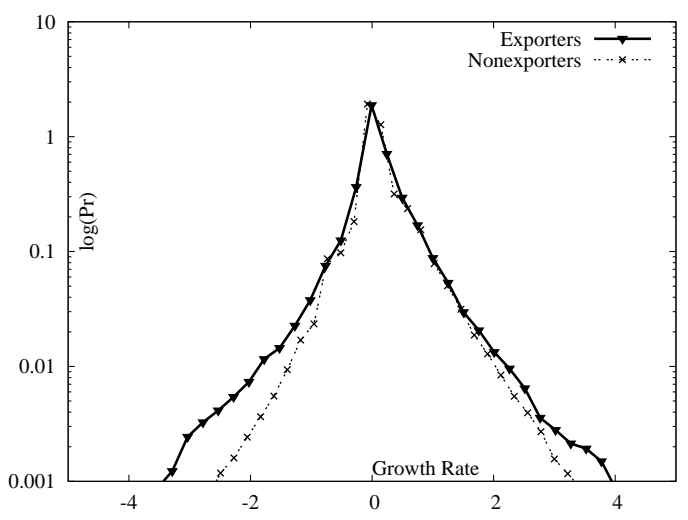

(a) Age $<5$

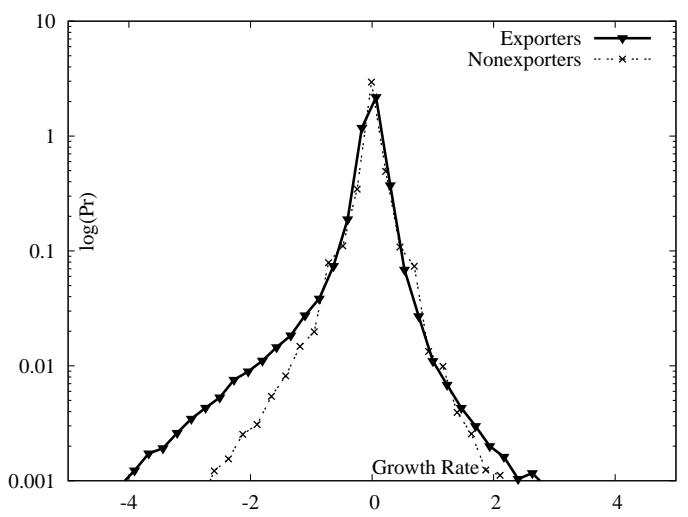

(c) Age 11-20

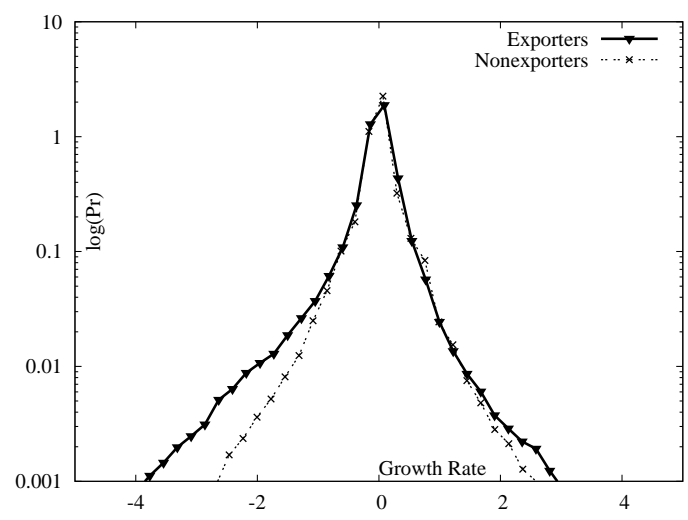

(b) Age 5-10

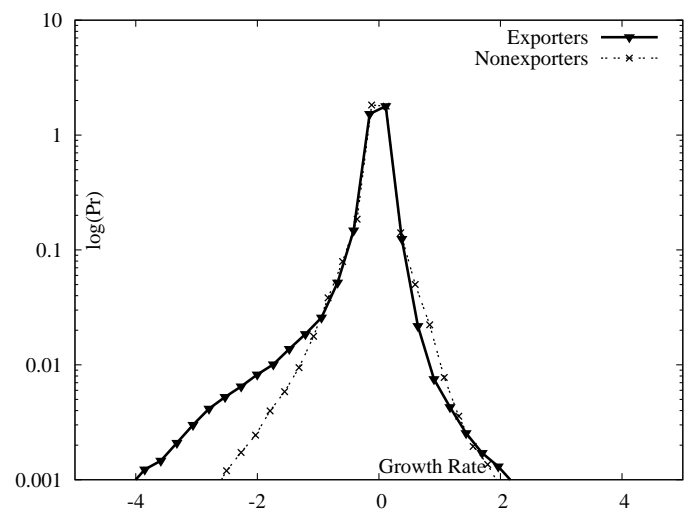

(d) Age 21+

Figure 3: Kernel density estimation of employment growth rates for exporters and nonexporters, by age class. Pooled data over 2000-2006.

2001). As expected, the right tail of the size distribution is much similar to that computed on the left-truncated sample available in previous version of the same dataset (Bottazzi et al., 2007). In 2001 the modal value for the number of people working in a firm is one. These figures confirm the known evidence of the Italian industrial structure characterized by an overwhelming majority of small-medium firms that faces many difficulties to expand (Dosi et al., 2012). ${ }^{11}$

As far as the differences in export status are concerned, Figure 3 presents the growth rate distributions for exporters and nonexporters by age class, pooled over the years. We define exporters based on the firm's export status at time $t-1$.

Quite interestingly, across the four age classes, the support of the distributions of growth rates for both exporters and non exporters appears to shrink, especially on the right: high-growth firms are mostly young firms. This is consistent with some recent empirical evidence from other countries (see Coad et al., 2013 for Spain, and Barba Navaretti et al., 2014 for a comparative perspective across France, Italy, and Spain) and broadly in tune with theoretical learning models of firm growth á la Jovanovic, which predict that younger firms have both higher and more variable growth rates (Jovanovic,

\footnotetext{
${ }^{11}$ Also notice that performing a similar exercise to that in Hsieh and Klenow (2014), we find that Italian firms in the 30-34 age class are only around 3 times bigger than those of the 10-14 age class. This is a somewhat smaller than the 6.5 factor reported in Hsieh and Klenow (2014) which employed a more limited set of data.
} 


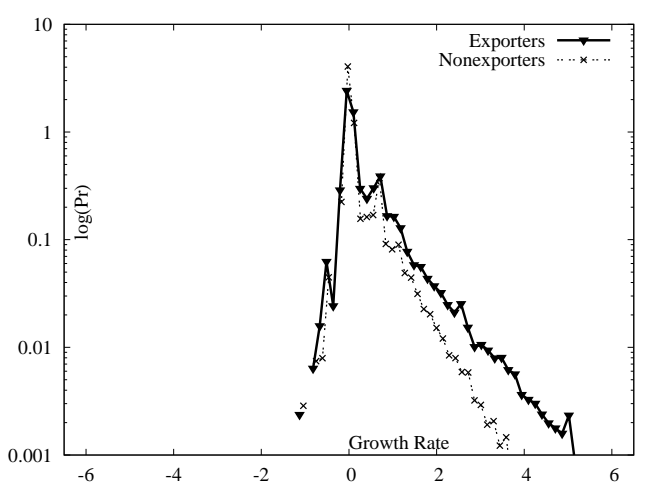

(a) Size 1

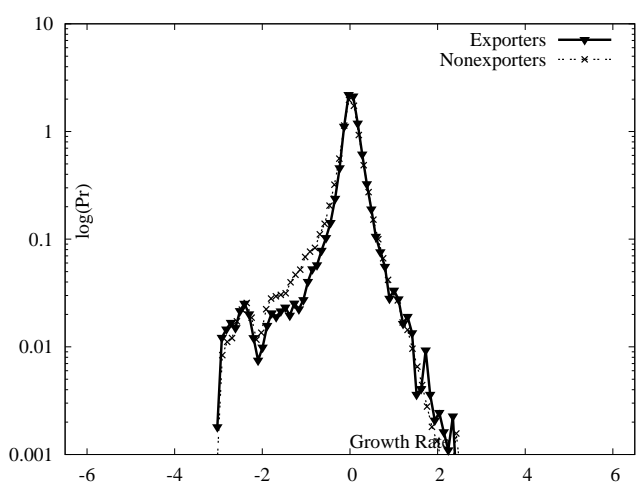

(c) Size 10-19

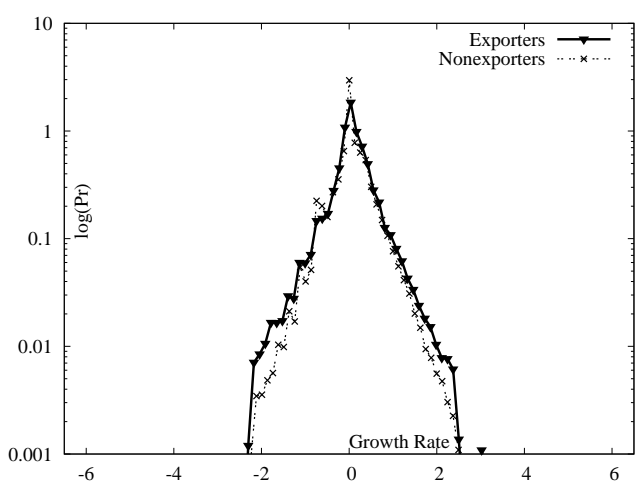

(b) Size 2-9

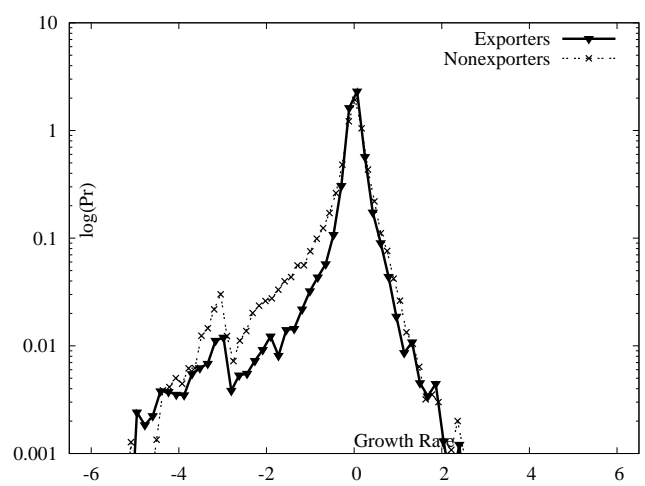

(d) Size 20+

Figure 4: Kernel density of employment growth rates for young (age $<5$ ) exporters and nonexporters, by size class. Pooled data over 2000-2006.

1982).

Focusing on the differences related to the export status, it appears that exporters have higher dispersion in their growth rates than non exporters. In particular, among younger firms (age $<5$ and age 5-10), both high-growth and low-growth firms are mostly exporters. Among older firms (age 11-20 and age 21+), the higher dispersion of exporters growth rates is mainly driven by the larger magnitude of downsizing episodes.

Figure 4 shows, only for young firms, the distributions of growth rates of exporters and non exporters broken down by size class. Among firms born in the last five years, the bigger ones experience less frequently large growth episodes (the right tail is steeper), whereas the probability of a downsizing becomes more likely (the left tail is not a straight line but more convex to the origin). As for the difference related to the export status, exporters display a distribution of growth rates more concentrated around the mode among firms of bigger size (10-19 and bigger than 20 employees), whereas the opposite happens among smaller firms (1 and 2-9).

We now move from graphical inspection to a formal test of the distributional equality between exporters and nonexporters. A range of tests are in principle available. There are however some specific features of our data which must be carefully considered in selecting the most appropriate alternative. First of all, the number of firms within the groups of exporters and non-exporters does not need to be the same, and therefore we would need a test for the case of two uneven samples. Second, other works employing similar data and variables (see for instance Bottazzi et al., 2007; Grazzi, 2012) have shown that the dis- 
Table 5: Fligner-Policello test of stochastic equality

\begin{tabular}{lrrrr}
\hline & \multicolumn{4}{c}{ Size class } \\
Age class & 1 & $2-9$ & $10-19$ & $20+$ \\
\hline Age $<5$ & 19.84 & 30.73 & 9.56 & 9.45 \\
& $(0.00)$ & $(0.00)$ & $(0.00)$ & $(0.00)$ \\
Age 5-10 & -13.85 & -4.31 & 3.68 & 16.27 \\
& $(0.00)$ & $(0.00)$ & $(0.00)$ & $(0.00)$ \\
Age 11-20 & -11.62 & -5.62 & 0.08 & 17.26 \\
& $(0.00)$ & $(0.00)$ & $(0.93)$ & $(0.00)$ \\
Age 21+ & -4.4 & -0.33 & -6.27 & 8.2 \\
& $(0.00)$ & $(0.74)$ & $(0.00)$ & $(0.00)$ \\
\hline
\end{tabular}

Note. Distributional comparison between growth rates of exporters and nonexporters. Pooled data over 2000-2006. p-value in parentheses.

tributions we are going to compare display clear non-normalities and unequal variances, suggesting that non-parametric tests should be preferred over parametric ones. Further, within the class of non-parametric tests, a common feature is to implicitly assume that the samples to be compared only differ for a shift of location, while their distributions possess identical shapes. However, when distributions with different shapes are compared, looking at the relative location of medians, modes or means might no longer be very informative, as the very meaning of these measures changes with the nature of the underlying distribution. The Fligner-Policello (FP) test does not require neither equal shapes nor symmetry for the in comparisons of two distributions.

Let $F_{E}$ and $F_{N E}$ be the distributions of growth rates of exporters and nonexporters. Denote with $\boldsymbol{X}_{E} \sim F_{E}$ and $\boldsymbol{X}_{N E} \sim F_{N E}$ the associated random variables, and with $X_{E}$ and $X_{N E}$ two respective realizations. The distribution $F_{E}$ is said to have stochastic dominance over $F_{N E}$ if Prob $\left\{X_{E}>X_{N E}\right\}>1 / 2$. That is, if one randomly selects one exporter and one nonexporter, the former has a higher probability of having a greater value. Remembering the equality:

$$
\operatorname{Prob}\left\{X_{E}>X_{N E}\right\}=\int d F_{E}(X) F_{N E}(X)
$$

the statistical test to assess which of the two distributions dominates over the other can be formulated as a test of

$$
H_{0}: \int d F_{E} F_{N E}=\frac{1}{2} \text { vs } H_{1}: \int d F_{E} F_{N E} \neq \frac{1}{2}
$$

The procedure developed in Fligner and Policello (1981) provides a valid statistic for $H_{0}$. Notice also that, in case of rejection of the null, the sign of the Fligner Policello (FP) statistic tells us which of the two groups of firms is dominant: a positive (negative) sign means that exporters (non-exporters) have a higher probability to experience higher growth rates.

Table 5 reports the results of the distributional comparison between exporters and nonexporters for each age-size class combination. Among firms less than 5 years old, the FP statistic is always positive and significant, meaning that the growth rate distribution of young exporters dominate the growth rate distribution of nonexporters. In the other age classes, the picture is less clear-cut. In general, we observe that, moving to older age 
Table 6: Growth, size, and export status

\begin{tabular}{lccccc}
\hline & $(1)$ & $(2)$ & $(3)$ & $(4)$ & $(5)$ \\
& All firms & Age $<5$ & Age 5-10 & Age 11-20 & Age 21+ \\
\hline$D_{i, t-1}^{\text {exp }}$ & $0.037^{* * *}$ & $0.074^{* * *}$ & $0.045^{* * *}$ & $0.025^{* * *}$ & $0.015^{* * *}$ \\
& $(0.001)$ & $(0.003)$ & $(0.002)$ & $(0.001)$ & $(0.001)$ \\
$\ln$ Size $_{i, t-1}$ & $-0.094^{* * *}$ & $-0.105^{* * *}$ & $-0.105^{* * *}$ & $-0.090^{* * *}$ & $-0.076^{* * *}$ \\
& $(0.001)$ & $(0.002)$ & $(0.001)$ & $(0.001)$ & $(0.001)$ \\
$\left(\ln \text { Size }_{i, t-1}\right)^{2}$ & $0.012^{* * *}$ & $0.004^{* * *}$ & $0.012^{* * *}$ & $0.013^{* * *}$ & $0.010^{* * *}$ \\
& $(0.000)$ & $(0.001)$ & $(0.000)$ & $(0.000)$ & $(0.000)$ \\
$\ln$ Age $_{i, t}$ & $-0.043^{* * *}$ & & & & \\
& $(0.000)$ & & & & \\
\hline$N$ & $3,290,033$ & 625,439 & 782,253 & 888,512 & 993,829 \\
$R^{2}$ & 0.051 & 0.036 & 0.041 & 0.034 & 0.030 \\
\hline
\end{tabular}

Note. Dummies for years, 2-digits sectors, and geographical location (provinces) included. Robust standard errors clustered at the firm-level in parentheses. ${ }^{*} p<0.10$, ** $p<0.05,{ }^{* * *} p<0.01$

classes, exporters dominate over nonexporters in fewer size classes. Among firms with age between 5 and 10 years, the statistics is positive and significant for firms in the third and fourth size class; in the last two age classes, the difference is still positive only among big firms $(21+)$. In the remaining cases, the statistics is either not significant or negative (six cases), meaning that nonexporters dominate over exporters.

\section{Export participation and firm growth}

The descriptive and statistical analysis performed so far has already put forth some compelling evidence on the role of firm size, age and the export status. Whether the number of firms is much concentrated in the smaller size classes, the largest share of employment is accounted for by firms belonging to the class of largest size. Exporting is a rather rare event and even more so for young (and small) firms. However the FP test of stochastic equality shows that it is for such category, young firms, that being in the export status exerts the most apparent effect in telling apart the distribution of exporting and non exporting firms.

This section uses a multivariate regression framework to investigate how export activity and size are related to firm growth within each age class. Our dependent variable, $g_{i, t}$, is the growth rate of firm $i$ at time $t$, and is defined, as before, as the log-difference between firm's employment in two consecutive years. We relate $g_{i, t}$ to the regressors through the following specification:

$$
g_{i, t}=c+\alpha D_{i, t-1}^{e x p}+\beta \ln \operatorname{Size}_{i, t-1}+\gamma\left(\ln \text { Size }_{i, t-1}\right)^{2}+\varepsilon_{i, t}
$$

where $D_{i, t-1}^{\exp }$ is a binary variable taking value one if the firm exports, and zero otherwise, $S i z e_{i, t-1}$ is the firm's employment, which also appears with its square $\left(\ln S i z e_{i, t-1}\right)^{2}$ to account for non linearity in the relationship (for similar specifications, see Evans, 1987b; Lawless, 2014).

Results from OLS estimation of Equation (2) are presented in Table 6, with the first column pooling all firms and taking into account also the role of age $\left(\ln A g e_{i, t}\right)$, and the 
remaining columns showing the results separately for each age class. Column (1) shows that, controlling for size, firm growth decreases with age and that exporters enjoy, on average, an increase in growth rate of 3.7\%. This supports our earlier finding that young firms grow more, and also underlines the additional advantage deriving from being an exporter. Columns (2)-(5) test whether the export premium remains significant when the relationship is estimated within each age class, and the answer is positive: both young and old exporters growth more than nonexporters, controlling for size. More interestingly, the coefficients on $D_{i, t-1}^{\exp }$ decline through the four age classes, with the differences being statistically significant: the positive effect associated to the export status is strongest among young firms.

The coefficient on $\ln S i z e_{i, t-1}$ is negative and significant, whereas that on $\left(\ln S i z e_{i, t-1}\right)^{2}$ is positive and significant, and both are declining, in absolute values, throughout the four age categories. This implies that, contrary to the prediction of the Gibrat's law, growth and size are not independent, but firm growth decreases with firm size, and the negative effect of size is lower for older firms. It is worth noticing, moreover, that the magnitude of the coefficients are not negligible, implying that an increase of one unit in employment is related to an average decrease in growth rate of around $10 \%$ for firms less than five years old.

One possible concern related to the results of Table 6 is that the variation in the effect of being exporter at different ages might be due to having different export shares at different ages. ${ }^{12}$ In order to check whether this might be the case, we first compute the average export share across age categories for the years 2000 and 2003, the only ones in which we have information on firm total sales. It turns out that export share does not change much with age. ${ }^{13}$ Then, we estimate Equation (2) by adding among the independent variables the firm-level export share and its square. Results for the two years in which we can compute export shares confirm that the coefficients on $D_{i, t-1}^{\exp }$ are positive, significant, and declining across age categories. Finally, notice that the results of Table 6 continue to hold when we consider separate cross-sections for each of the six years for which we can compute employment growth rates. In this case, the average values of the coefficients across years are strikingly similar to those reported in Table $6 .{ }^{14}$

In columns (2)-(5) of Table 6, we assume that the effect of exporting change across age categories, conditional on firm size. As a further robustness check, we also estimate the effect of exporting under the assumption that it changes both across age and across size categories. In particular, we estimate a fully saturated model encompassing the export status dummy, the age class dummies, and the size class dummies (as from Table 3), an approach similar to the one used by Haltiwanger et al. (2013) who, however, do not consider the export dimension. In Table 7 we report the differences in growth rates of exporters and non exporters for each age-size class, based both on the unweighted (columns 1) and on the employment-weighted specification (columns 2). This implies that the difference in columns 2 can be interpreted also as differences between aggregate growth rates of exporters and nonexporters within the specified category. It is apparent that, with few exceptions, growth rates of exporters are always bigger than growth rate of non exporters. For the weighted specification the difference is always positive in the first age class and, within each size class, it is bigger for young firms. These results confirm

\footnotetext{
${ }^{12}$ We thank one of the referees for raising this point.

${ }^{13}$ In 2000, we have an average export share of $22 \%$ for firms in the first age class, $23 \%$ for firms in the second and third age class, and 25\% for firms in the last age class. Patterns for 2003 are similar.

${ }^{14}$ These additional results are available upon requests.
} 
Table 7: Differences in growth rates between exporters and non exporters

\begin{tabular}{|c|c|c|c|c|c|c|c|c|}
\hline \multirow{3}{*}{ Age Class } & \multicolumn{8}{|c|}{ Size class } \\
\hline & \multicolumn{2}{|c|}{1} & \multicolumn{2}{|c|}{$2-9$} & \multicolumn{2}{|c|}{$10-19$} & \multicolumn{2}{|c|}{$20+$} \\
\hline & (1) & $(2)$ & (1) & (2) & (1) & $(2)$ & (1) & (2) \\
\hline Age $<5$ & 14.98 & 13.81 & 3.02 & 1.46 & 4.67 & 3.16 & 9.05 & 5.83 \\
\hline Age 5-10 & 9.00 & 8.37 & 0.96 & -0.05 & 2.99 & 1.98 & 6.92 & 4.00 \\
\hline Age 11-20 & 9.01 & 8.36 & -0.48 & -1.61 & 1.23 & 0.36 & 2.81 & 0.16 \\
\hline Age $21+$ & 10.22 & 13.26 & -1.49 & -2.70 & -0.62 & -1.23 & 1.30 & -1.26 \\
\hline
\end{tabular}

Note. The table reports differences in growth rates of exporters and non exporters, calculated from a fully saturated model with the export status dummy, the age class dummies, and the size class dummies. Columns (1) reports the result from the unweighted specification, whereas columns (2) reports the result from the employment-weighted specification. Dummies for years, 2-digits sectors, and geographical location (provinces) included.

Table 8: Growth, size, and export status: excluding nonemployer firms

\begin{tabular}{lccccc}
\hline & $(1)$ & $(2)$ & $(3)$ & $(4)$ & $(5)$ \\
& All firms & Age $<5$ & Age 5-10 & Age 11-20 & Age 21+ \\
\hline$D_{i, t-1}^{\text {exp }}$ & $0.058^{* * *}$ & $0.061^{* * *}$ & $0.057^{* * *}$ & $0.040^{* * *}$ & $0.035^{* * *}$ \\
& $(0.001)$ & $(0.003)$ & $(0.002)$ & $(0.001)$ & $(0.001)$ \\
$\ln$ Size $_{i, t-1}$ & $-0.338^{* * *}$ & $-0.551^{* * *}$ & $-0.378^{* * *}$ & $-0.291^{* * *}$ & $-0.173^{* * *}$ \\
& $(0.002)$ & $(0.004)$ & $(0.004)$ & $(0.004)$ & $(0.002)$ \\
$\left(\ln \text { Size }_{i, t-1}\right)^{2}$ & $0.051^{* * *}$ & $0.083^{* * *}$ & $0.060^{* * *}$ & $0.048^{* * *}$ & $0.024^{* * *}$ \\
& $(0.000)$ & $(0.001)$ & $(0.001)$ & $(0.001)$ & $(0.000)$ \\
$\ln$ Age $_{i, t}$ & $-0.059^{* * *}$ & & & & \\
& $(0.000)$ & & & & \\
\hline$N$ & $1,834,255$ & 313,653 & 421,907 & 501,909 & 596,786 \\
$R^{2}$ & 0.179 & 0.243 & 0.150 & 0.105 & 0.060 \\
\hline
\end{tabular}

Note. Dummies for calendar years, 2-digits sectors, and geographical location (provinces) included. Robust standard errors clustered at the firm-level in parentheses. ${ }^{*} p<0.10,{ }^{* *} p<0.05,{ }^{* * *} p<0.01$

the main message of Table 6 .

Finally, in order to provide a closer comparison of our results to previous works using only employer firms (see, for example, Haltiwanger et al., 2013), we estimate Equation 2 after excluding firms without employees. Results are reported in Table 8. Looking at column (1), we observe that both the coefficient on $\ln A g e_{i, t}$ and $D_{i, t-1}^{\exp }$ are still significant and with the expected sign. Columns (2)-(5) show that the export premium declines across the age classes. Greater differences are observed for coefficient on $\ln S_{i z e_{i, t-1}}$ and $\left(\ln S_{i z e_{i, t-1}}\right)^{2}$. As before, we observe that the effect of size on growth is declining in firm age and size, with point estimates which are now much larger. The departure from the Gibrat's law appears to be even stronger when we exclude non employer firms.

Finally, notice that all these results may well underestimate the advantage of young exporters with respect to non exporters since we do not consider firms that export indirectly. ${ }^{15}$ As indirect exporters are likely to be for the most part small and young, we are possibly counting among non exporters firms that do indeed export, although indirectly.

\footnotetext{
${ }^{15}$ We thank one of the referee for drawing our attention on this issue.
} 
Table 9: Growth, size, and export status: accounting for entry and exit

\begin{tabular}{|c|c|c|c|c|c|}
\hline & $\begin{array}{l}(1) \\
\text { All firms }\end{array}$ & $\begin{array}{c}(2) \\
\text { Age }<5\end{array}$ & $\begin{array}{c}(3) \\
\text { Age } 5-10\end{array}$ & $\begin{array}{c}(4) \\
\text { Age } 11-20\end{array}$ & $\begin{array}{c}(5) \\
\text { Age } 21+\end{array}$ \\
\hline$D_{i, t-1}^{\exp }$ & $\begin{array}{c}0.047^{* * *} \\
(0.001)\end{array}$ & $\begin{array}{c}0.051^{* * *} \\
(0.003)\end{array}$ & $\begin{array}{c}0.063^{* * *} \\
(0.002)\end{array}$ & $\begin{array}{c}0.029^{* * *} \\
(0.002)\end{array}$ & $\begin{array}{c}0.011^{\text {*** }} \\
(0.002)\end{array}$ \\
\hline $\ln S i z e_{i, t-1}$ & $\begin{array}{c}0.025^{* * *} \\
(0.001)\end{array}$ & $\begin{array}{c}-0.050^{* * *} \\
(0.002)\end{array}$ & $\begin{array}{c}0.018^{* * *} \\
(0.002)\end{array}$ & $\begin{array}{c}0.028^{* * *} \\
(0.001)\end{array}$ & $\begin{array}{c}0.057^{* * *} \\
(0.001)\end{array}$ \\
\hline $\ln \left(S i z e_{i, t-1}\right)^{2}$ & $\begin{array}{l}-0.000 \\
(0.000)\end{array}$ & $\begin{array}{c}0.000 \\
(0.001)\end{array}$ & $\begin{array}{c}-0.002^{* * *} \\
(0.000)\end{array}$ & $\begin{array}{c}-0.002^{* * *} \\
(0.000)\end{array}$ & $\begin{array}{c}-0.006^{* * *} \\
(0.000)\end{array}$ \\
\hline $\ln A g e_{i, t}$ & $\begin{array}{c}-0.172^{* * *} \\
(0.000)\end{array}$ & & & & \\
\hline$N$ & $3,815,964$ & 890,510 & 881,785 & 966,694 & $1,076,975$ \\
\hline$R^{2}$ & 0.058 & 0.006 & 0.010 & 0.009 & 0.012 \\
\hline
\end{tabular}

\subsection{Entry and exit}

Results of the previous section only considered the standard definition of growth which requires the existence of the firm in two consecutive years. We now estimate Equation (2) by taking into account also entry and exit. To this end, we redefine firm growth rate, $g_{i, t}$, as follows:

$$
g_{i, t}^{\prime}=\left(S i z e_{i, t}-S i z e_{i, t-1}\right) / S i z e_{i, t}^{a v g}
$$

where

$$
S i z e_{i, t}^{a v g}=0.5 *\left(\text { Size }_{i, t}+\text { Size }_{i, t-1}\right)
$$

This measure of growth is often used in the analysis of firm and employment dynamics (Davis et al., 1996; Haltiwanger et al., 2013; Lawless, 2014) in order to accommodate entry and exit. It is a symmetric growth rate measure, like the log first difference, but it is also bounded between -2 (exit) and 2 (entrant).

When estimating Equation (2) with the dependent variable $g_{i, t}^{\prime}$, we measure, as before, firm size and export status at time $t-1$ for all firms except entrants. For new firms, we follow Haltiwanger et al. (2013) and others and measure their characteristics at time $t$. Results from OLS estimation are reported in Table 9.

Start by noting that coefficients on $D_{i, t-1}^{\exp }$ are still positive and significant across the four age categories. The only difference with respect to the previous results is that now the biggest effect of exporting is to be found among firms in the age class 5-10. The relative underperformance of young exporters with respect to more mature ones is possibly due to the role of entrants, which are for the most part concentrated in the age class $<5$.

The other difference with respect to Table 6 is related to the sign of the coefficients on $\ln S i z e_{i, t-1}\left(\right.$ and $\left.\ln \left(S i z e_{i, t-1}\right)^{2}\right)$. It is apparent that, after accounting for entry and exit, no systematic relationship seems to emerge between size and growth. The coefficient is negative among young firms, where the negative effect of size on growth among continuing firms is reinforced by the positive correlation between age and entry. On the other hand, 
the coefficient is positive among older firms, where the exit dynamics dominate and "favour" bigger firms, which are less likely to die.

Overall, these patterns show that, contrary to recent findings (see Haltiwanger et al., 2013; Lawless, 2014), size impacts on firm growth rates of continuing firms even after taking into account the role of age; however, when we consider also entry and exit, the role of size becomes less systematic: we still observe a violation of the Gibrat's hypothesis of independence, that goes in different directions depending on firm age.

\subsection{Young exporters and product-country destinations}

In this section, we take advantage of the finer level of detail that is available for exports over the years 2000-2006 (Section 2) and we disaggregate total firm's exports in a given year, in the sum of exports to each product-country destination served by the firm in that year.

As standard in the trade literature (see for instance Bernard et al., 2007) a firm's total exports to a product-country destination can be decomposed into extensive (quantity) and intensive margins (unit values), ${ }^{16}$

$$
\ln X_{f p c}=\ln \text { Quantity }_{f p c}+\ln \text { UnitValue }_{f p c}
$$

where $\ln X_{f p c}$ is the $\log$ value (in euro) of exports by firm $f$ in product $p$ to country $c$, Quantity $f p c$ is the physical quantity of the good $p$ exported to country $c$ and UnitValue $X_{f p c}$ is the unit value of the transaction in that year. Such disaggregation of course results in a larger number of observations which we employ, first, to compare young exporters and older exporters within product-country destinations, and second, to study the sensitivity of young firms and older firms to annual exchange rate movements by considering export value, quantity and unit value.

Using exports to Extra-EU destinations, we estimate the following regression equation: ${ }^{17}$

$$
\ln Y_{f p c}=c+\alpha D_{f}^{\text {young }}+\beta \ln \text { Size }_{f}+\gamma \ln \text { \#transactions }_{f}+d_{p c}+\varepsilon_{f p c}
$$

where $\ln Y_{f p c}$ denotes the logarithm of, respectively, the total value, quantity and unit value of the firms exports in the country-product pair, $D_{f}^{\text {young }}$ is a dummy for firms with Age $<5, \ln$ Size $_{f}$ is the log of employment, ln \#transactions $s_{f}$ is the log of total number of cross-border transactions (product-country) and $d_{p c}$ denotes country-product fixed effects. Controlling for the number of transactions is important as young firms are less diversified in terms of destinations and products and so they concentrate more their exports. ${ }^{18}$ The results in the first column of Table 10 show that, without controlling for size and number of transactions, young exporters have a substantially lower total value of exports relative to older exporters within product-country pairs. This is not surprising: even if young firms report similar export shares than older firms (see Section 4), they

\footnotetext{
${ }^{16}$ For a detailed description of the transaction level trade data and the product classification employed refer to Bernard et al. (2015).

${ }^{17}$ We focus on exports to Extra-EU destinations for several reasons. Most importantly, firm-level exports to the EU are not recorded for all exporters and these criteria have changed over time. Also, real exchange rate changes within the eurozone countries are driven entirely by changes in relative price levels.

${ }^{18}$ In 2000, firms with less than 5 years reported, on average, around 96 cross-border transactions, whereas older firms around 220. We thank one of the referees for raising this point.
} 
are smaller in absolute terms (see Table 3). However, the difference in exports across firm types change sign after controlling for firm employment and number of transactions (column (2)): in six out of the seven years of our sample, we find that young firms are able to record higher exports than older firms. Columns 3-6 report the decomposition of the results as accounted by quantity and unit values. The difference in exports are mainly driven by differences in export quantities; in most cases, unit values are not statistically different for young and older exporters. Notice also that these results are largely unchanged when we do not control for the number of transactions, and when control for (log) sales instead of (log) employment for the two years (2000 and 2003) in which this information is available. Moreover, the results continue to hold when we compare young exporters in 2006 with older firms that were already exporting for at least four years. ${ }^{19}$

These results provide a first evidence in support of the hypothesis of a different behavior of young and well established exporters. Quite surprisingly, we do find that "bornglobal" firms are able to perform at least as well, and in many cases better than, more experienced firms in terms of exports and quantity sold on foreign markets. Although, we cannot further interpret such result here, this finding is for instance consistent with the evidence of Huergo and Jaumandreu (2004b,a), who show that young firms have a higher propensity to innovate; the higher innovativeness of young firms might in turn impact on their competitiveness (Dosi et al., 2015a). Since the analysis presented above about the levels of exports does not allow to control for unobservable characteristics that might be specific to the firm (or to the firm-product varieties), we expand our analysis to correct for such potential source of bias.

In the following analysis, we control for firm, as well as for firm-product specific effects by studying the differential response of firms' exports to an exogenous shock, such as real exchange rates variations. In particular, following an emerging stream of empirical literature in international trade we investigate how different firms, in our case born globals and established exporters, respond to the same exogenous shock within a product-country destination, and how such effects is accounted for by quantity and unit values variations (see among the others, Berman et al., 2012; Chatterjee et al., 2013).

The regression framework that we consider is

$$
\Delta \ln Y_{f p c t}=c+\alpha D_{f t}^{y o u n g}+\beta \Delta \ln R E R_{c t}+\gamma \Delta \ln R E R_{c t} * D_{f t}^{y o u n g}+d_{j}+\varepsilon_{f p c t}
$$

where $\Delta \ln Y_{f p c t}$ is the change (log difference) in firm-level product-country export value, quantity or unit value, $D_{f t}^{\text {young }}$ is a dummy for firms with $A g e<5, \Delta \ln R E R_{c t}$ is the change in the log of the real bilateral exchange rate of the Italian currency which is computed with data from the International Financial Statistics database. $R E R_{c t}$ for each year is the product between the nominal Italian exchange rate expressed as the number of foreign currency units per home currency unit $\left(E R_{c t}\right)$ and the ratio of the domestic consumer price level and the consumer price index abroad $\left(\frac{C P I_{t}}{C P I_{c t}}\right) \cdot{ }^{20} \Delta \ln R E R_{c t} * D_{f t}^{y o u n g}$ is their interaction, and $d_{j}$ a set of of fixed effects.

Results in Table 11 show that while the volume of exports to a given product-country destination (Col. 1 and 2) decreases for all firms following a currency appreciation, such reduction is cut by more than half (Col. 2) for young firms, as accounted by the

\footnotetext{
${ }^{19}$ These additional results are available upon request.

${ }^{20}$ We employ the Consumer Price Index as it provides data for many more countries than the Wholesale Price Index.
} 
Table 10: Firm's exports, quantity, and unit value by product and country, by different type of firms

\begin{tabular}{|c|c|c|c|c|c|c|}
\hline & $\begin{array}{c}(1) \\
\ln X_{f c p t}\end{array}$ & $\begin{array}{c}(2) \\
\ln X_{f c p t}\end{array}$ & $\begin{array}{c}(3) \\
\ln \text { Quantity }_{f c p t}\end{array}$ & $\begin{array}{c}(4) \\
\ln \text { Quantity }_{f c p t}\end{array}$ & $\begin{array}{c}(5) \\
\ln \text { UnitValue }_{f c p t}\end{array}$ & $\begin{array}{c}(6) \\
\ln \text { UnitValue }_{f p p t}\end{array}$ \\
\hline \multicolumn{7}{|l|}{2000} \\
\hline$\overline{D_{f}^{\text {young }}}$ & $\begin{array}{c}-0.146^{* * *} \\
(0.015)\end{array}$ & $\begin{array}{c}0.071^{* * *} \\
(0.012)\end{array}$ & $\begin{array}{c}-0.122^{* * *} \\
(0.022)\end{array}$ & $\begin{array}{c}0.083^{* * *} \\
(0.022)\end{array}$ & $\begin{array}{l}-0.024 \\
(0.016)\end{array}$ & $\begin{array}{l}-0.012 \\
(0.016)\end{array}$ \\
\hline $\ln S_{i z e_{f}}$ & & $\begin{array}{c}0.223^{* * *} \\
(0.005)\end{array}$ & & $\begin{array}{c}0.256^{* * *} \\
(0.007)\end{array}$ & & $\begin{array}{c}-0.033^{* * *} \\
(0.005)\end{array}$ \\
\hline $\ln \#$ transactions $s_{f}$ & & $\begin{array}{c}0.014^{* * *} \\
(0.005)\end{array}$ & & $\begin{array}{c}-0.055^{* * *} \\
(0.007)\end{array}$ & & $\begin{array}{c}0.069^{* * *} \\
(0.005)\end{array}$ \\
\hline Country-Product FE & Yes & Yes & Yes & Yes & Yes & Yes \\
\hline & 976,185 & 976,185 & 975,780 & 975,780 & 975,780 & 975,780 \\
\hline $\operatorname{adj} . R^{2}$ & 0.160 & 0.200 & 0.402 & 0.419 & 0.641 & 0.643 \\
\hline \multicolumn{7}{|l|}{2001} \\
\hline$D_{f}^{\text {young }}$ & $\begin{array}{c}-0.151^{* * *} \\
(0.016)\end{array}$ & $\begin{array}{l}0.038^{* *} \\
(0.013)\end{array}$ & $\begin{array}{c}-0.142^{* * *} \\
(0.023)\end{array}$ & $\begin{array}{c}0.037 \\
(0.024)\end{array}$ & $\begin{array}{l}-0.008 \\
(0.018)\end{array}$ & $\begin{array}{c}0.002 \\
(0.018)\end{array}$ \\
\hline \multicolumn{7}{|l|}{2002} \\
\hline$D_{f}^{\text {young }}$ & $\begin{array}{c}-0.149^{* * *} \\
(0.015)\end{array}$ & $\begin{array}{l}0.025^{*} \\
(0.013) \\
\end{array}$ & $\begin{array}{c}-0.144^{* * *} \\
(0.022)\end{array}$ & $\begin{array}{c}0.021 \\
(0.023) \\
\end{array}$ & $\begin{array}{c}-0.004 \\
(0.016) \\
\end{array}$ & $\begin{array}{c}0.005 \\
(0.016)\end{array}$ \\
\hline \multicolumn{7}{|l|}{2003} \\
\hline$D_{f}^{\text {young }}$ & $\begin{array}{c}-0.114^{* * *} \\
(0.016) \\
\end{array}$ & $\begin{array}{c}0.054^{* * *} \\
(0.013) \\
\end{array}$ & $\begin{array}{c}-0.114^{* * *} \\
(0.024) \\
\end{array}$ & $\begin{array}{l}0.045^{* *} \\
(0.023) \\
\end{array}$ & $\begin{array}{c}0.001 \\
(0.017) \\
\end{array}$ & $\begin{array}{c}0.010 \\
(0.017) \\
\end{array}$ \\
\hline \multicolumn{7}{|l|}{2004} \\
\hline$D_{f}^{\text {young }}$ & $\begin{array}{c}-0.082^{* * *} \\
(0.019)\end{array}$ & $\begin{array}{c}0.066^{* * *} \\
(0.017)\end{array}$ & $\begin{array}{c}-0.093^{* * *} \\
(0.026)\end{array}$ & $\begin{array}{l}0.044^{*} \\
(0.025)\end{array}$ & $\begin{array}{c}0.011 \\
(0.016)\end{array}$ & $\begin{array}{c}0.023 \\
(0.016)\end{array}$ \\
\hline \multicolumn{7}{|l|}{2005} \\
\hline$D_{f}^{\text {young }}$ & $\begin{array}{c}-0.099^{* * *} \\
(0.022)\end{array}$ & $\begin{array}{l}0.043^{*} \\
(0.023)\end{array}$ & $\begin{array}{c}-0.123^{* * *} \\
(0.030)\end{array}$ & $\begin{array}{l}-0.000 \\
(0.031)\end{array}$ & $\begin{array}{c}0.024 \\
(0.018)\end{array}$ & $\begin{array}{l}0.042^{* *} \\
(0.018)\end{array}$ \\
\hline \multicolumn{7}{|l|}{2006} \\
\hline$D_{f}^{\text {young }}$ & $\begin{array}{c}-0.119^{* * *} \\
(0.020)\end{array}$ & $\begin{array}{l}-0.016 \\
(0.020)\end{array}$ & $\begin{array}{c}-0.129^{* * *} \\
(0.026)\end{array}$ & $\begin{array}{l}-0.006 \\
(0.027)\end{array}$ & $\begin{array}{c}0.011 \\
(0.019)\end{array}$ & $\begin{array}{c}0.023 \\
(0.018)\end{array}$ \\
\hline
\end{tabular}

Note. Table reports results of regressions at the firm product country level, using data on exports, quantity and unit value for years 2000-2006. Columns (2), (4) and (6) control for log of employment and number of transactions. We report coefficients on $\ln$ Size $_{f}$ and $\ln \#$ transactions $_{f}, N$ and adj. $R^{2}$ only for 2000 . Robust standard errors clustered at firm level in parenthesis. ${ }^{*} p<0.10,{ }^{* *} p<0.05,{ }^{* * *} p<0.01$

interaction term. Such evidence is much surprising as these firms are new comers, and it also lends support to the category of born globals as firms that are both highly efficient and already equipped to face unfavorable events. This result is further reinforced by the analysis of quantities and unit values as the smaller response of firms' exports is actually the result of two opposite effects: exchange rate pass-through is smaller (Col. 5 and 6 ) and quantity falls less (Col. 3 and 4).

Overall, the evidence from Table 11 suggests that young exporters react to exogenous exchange rate shocks in such a way as to minimize the losses in terms of exports and quantity growth rates; and they are able to achieve this by lowering their prices more than other established exporters. 
Table 11: Exchange rates and firm's exports, quantity, and unit value by product and country over time, by different type of firms

\begin{tabular}{|c|c|c|c|c|c|c|}
\hline \multicolumn{7}{|c|}{ Annual Differences } \\
\hline & $\begin{array}{c}(1) \\
\ln X_{f c p t}\end{array}$ & $\begin{array}{c}(2) \\
\ln X_{f c p t}\end{array}$ & $\begin{array}{c}(3) \\
\ln \text { Quantity }_{f c p t}\end{array}$ & $\begin{array}{c}(4) \\
\ln \text { Quantity }_{f c p t}\end{array}$ & $\begin{array}{c}(5) \\
\ln \text { UnitValue }_{f c p t}\end{array}$ & $\begin{array}{c}(6) \\
\ln \text { UnitValue }_{f c p t}\end{array}$ \\
\hline$D_{f t}^{\text {young }}$ & $\begin{array}{l}0.065^{* * *} \\
(0.005)\end{array}$ & & $\begin{array}{c}0.065^{* * *} \\
(0.005)\end{array}$ & & $\begin{array}{l}-0.000 \\
(0.002)\end{array}$ & \\
\hline$\Delta \ln R E R_{c t}$ & $\begin{array}{c}-0.282^{* * *} \\
(0.088)\end{array}$ & $\begin{array}{c}-0.342^{* * *} \\
(0.105)\end{array}$ & $\begin{array}{c}-0.248^{* * *} \\
(0.092)\end{array}$ & $\begin{array}{c}-0.313^{* * *} \\
(0.108)\end{array}$ & $\begin{array}{c}-0.033^{* * *} \\
(0.010)\end{array}$ & $\begin{array}{c}-0.029^{* * *} \\
(0.010)\end{array}$ \\
\hline$\Delta \ln R E R_{c t} * D_{f t}^{\text {young }}$ & $\begin{array}{l}0.073^{*} \\
(0.044)\end{array}$ & $\begin{array}{l}0.226^{* *} \\
(0.077)\end{array}$ & $\begin{array}{l}0.111^{* *} \\
(0.048)\end{array}$ & $\begin{array}{c}0.265^{* * * *} \\
(0.084)\end{array}$ & $\begin{array}{c}-0.039^{* * * *} \\
(0.016)\end{array}$ & $\begin{array}{l}-0.040^{*} \\
(0.020)\end{array}$ \\
\hline Country FE & Yes & Yes & Yes & Yes & Yes & Yes \\
\hline Product FE & Yes & No & Yes & No & Yes & No \\
\hline Firm-Product FE & No & Yes & No & Yes & No & Yes \\
\hline$N$ & $2,715,478$ & $2,715,478$ & $2,715,478$ & $2,715,478$ & $2,715,478$ & $2,715,478$ \\
\hline $\operatorname{adj} . R^{2}$ & 0.004 & -0.006 & 0.003 & -0.008 & 0.001 & 0.031 \\
\hline
\end{tabular}

Note. Table reports results of regressions at the firm product country level, using data on exports, quantity and unit value between 2000 and 2006. The dependent and independent variables are defined as annual differences. Robust standard errors clustered at country-year level in parenthesis. Year dummies included. ${ }^{*} p<0.10,{ }^{* *} p<0.05,{ }^{* * *}$ $p<0.01$

\section{Conclusions}

In this paper we have shown how size, age, and export status jointly concur to determine the different patterns of firm growth. In particular, we found that exporting firms grow more than non exporting firms conditional on size, and within each age category. The positive effect associated to the export status declines with age. We also found that small firms grow more than bigger ones, even when accounting for differences in their age. Further, notwithstanding their much limited experience, young exporters or born global appear to be well equipped to face unfavorable shocks, such as a real exchange rate appreciation.

These results may well support the idea that the attitude towards growth opportunities is a meaningful and sometimes neglected determinant of firms growth, as being involved in international activities at a very early stage is likely to capture both the capabilities of firms to compete on foreign markets and also their intention to "grab" new growth opportunities. Given the lack of any qualitative evidence in data, we could not investigate this issue at greater detail. However, we highlight how our results are consistent with the robust evidence that growth processes are also shaped by behavioural factors (as for instance suggested in Zahra et al., 2000; Knight and Cavusgil, 2004; Davidsson and Wiklund, 2013). Indeed the attitude of firms towards growth might be already apparent from the very early stage of firm's life-cycle and it represents one of the 'idiosyncratic' covariates regarding, so to speak, the "identity cards" of individual firms, ideally revealing also their technological and organizational capabilities (more in Dosi and Grazzi, 2006). 


\section{References}

Ahn, J., A. K. Khandelwal, And S.-J. Wei (2011): "The role of intermediaries in facilitating trade," Journal of International Economics, 84, 73-85.

ArIU, A. (forthcoming): "Services versus Goods Trade: A Firm-Level Comparison," Review of World Economics.

Arnold, J. M. And K. Hussinger (2005): "Export Behavior and Firm Productivity in German Manufacturing: A Firm-Level Analysis," Review of World Economics (Weltwirtschaftliches Archiv), 141, 219-243.

Axtell, R. L. (2001): "Zipf Distribution of US Firm Sizes," Science, 293, 1818-1820.

Barba Navaretti, G., D. Castellani, and F. Pieri (2014): "Age and firm growth: evidence from three European countries," Small Business Economics, 43, 823-837.

Berman, N., P. Martin, and T. Mayer (2012): "How do Different Exporters React to Exchange Rate Changes?" The Quarterly Journal of Economics, 127, 437-492.

Bernard, A. B., M. Grazzi, and C. Tomasi (2015): "Intermediaries in International Trade: Products and Destinations," The Review of Economics and Statistics, 97, 916920.

Bernard, A. B. And J. B. Jensen (2004): "Why Some Firms Export," The Review of Economics and Statistics, 86, 561-569.

Bernard, A. B., J. B. Jensen, S. J. Redding, And P. K. Schott (2007): "Firms in International Trade," Journal of Economic Perspectives, 21, 105-130.

(2010): "Wholesalers and Retailers in US Trade," American Economic Review, $100,408-13$.

Berthou, A. And V. Vicard (2015): "Firms' Export Dynamics: Experience Versus Size," The World Economy, 38, 1130-1158.

Birch, D. L. (1981): "Who creates jobs," Public Interest, 65, 3-14.

Bottazzi, G., E. Cefis, G. Dosi, and A. Secchi (2007): "Invariances and Diversities in the Evolution of Italian Manufacturing Industry," Small Business Economics, 29, $137-159$.

Bottazzi, G., A. Coad, N. Jacoby, And A. Secchi (2011): "Corporate growth and industrial dynamics: evidence from French manufacturing," Applied Economics, 43, 103-116.

Bottazzi, G., G. Dosi, N. Jacoby, A. Secchi, and F. Tamagni (2010): "Corporate performances and market selection: some comparative evidence," Industrial and Corporate Change, 19, 1953-1996.

Bottazzi, G. And A. Secchi (2006): "Explaining the Distribution of Firms Growth Rates," RAND Journal of Economics, 37, 235-256. 
Castellani, D. AND A. Zanfei (2007): "Internationalisation, innovation and productivity: how do firms differ in Italy?" The World Economy, 30, 156-176.

Chatterjee, A., R. Dix-Carneiro, and J. Vichyanond (2013): "Multi-product Firms and Exchange Rate Fluctuations," American Economic Journal: Economic Policy, 5, 77-110.

CoAd, A. (2007): "A Closer Look at Serial Growth Rate Correlation," Review of Industrial Organization, 31, 69-82.

(2009): The Growth of Firms: A Survey of Theories and Empirical Evidence, New Perspectives on the Modern Corporation, Edward Elgar, Cheltenham, UK.

(2010): "Investigating the exponential age distribution of firms," Economics - The Open-Access, Open-Assessment E-Journal, 4, 1-30, http://dx.doi.org/10.5018/economics-ejournal.ja.2010-17.

Coad, A., A. Segarra, And M. Teruel (2013): "Like milk or wine: Does firm performance improve with age?" Structural Change and Economic Dynamics, 24, 173 $-189$.

Coad, A. And J. TAmvada (2012): "Firm growth and barriers to growth among small firms in India," Small Business Economics, 39, 383-400.

Davidsson, P. (1989): "And After? A study of growth willingness in small firms," Journal of Business Venturing, 4, 211-226.

Davidsson, P. And J. Wiklund, eds. (2013): New Perspectives On Firm Growth, Edward Elgar, Cheltenham, UK.

Davis, S. J. And J. Haltiwanger (1992): "Gross Job Creation, Gross Job Destruction, and Employment Reallocation," Quarterly Journal of Economics, 107, 819-863.

Davis, S. J., J. Haltiwanger, R. S. Jarmin, C. Krizan, J. Miranda, A. Nucci, And K. SAndusky (2009): "Measuring the Dynamics of Young and Small Businesses: Integrating the Employer and Nonemployer Universes," in Producer Dynamics: New Evidence from Micro Data, National Bureau of Economic Research, Inc, NBER Chapters, 329-366.

Davis, S. J., J. C. Haltiwanger, And S. Schuh (1996): Job Creation and Destruction, MIT Press: Cambridge, MA.

Dosi, G. AND M. Grazzi (2006): "Technologies as problem-solving procedures and technologies as input-output relations: some perspectives on the theory of production," Industrial and Corporate Change, 15, 173-202.

Dosi, G., M. Grazzi, L. Marengo, and S. Settepanella (forthcoming): "Production theory: accounting for firm heterogeneity and technical change," Journal of Industrial Economics.

Dosi, G., M. Grazzi, And D. Moschella (2015a): "Technology and costs in international competitiveness: from countries and sectors to firms," Research Policy, 44, $1795-1814$. 
Dosi, G., M. Grazzi, C. Tomasi, And A. Zeli (2012): "Turbulence underneath the big calm? The micro-evidence behind Italian productivity dynamics," Small Business Economics, 39, 1043-1067.

Dosi, G., D. Moschella, E. Pugliese, and F. Tamagni (2015b): "Productivity, market selection and corporate growth: comparative evidence across US and Europe," Small Business Economics, 45, 643-672.

Evans, D. S. (1987a): "The Relationship between Firm Growth, Size, and Age: Estimates for 100 Manufacturing Industries," Journal of Industrial Economics, 35, 567-81. (1987b): "Tests of Alternative Theories of Firm Growth," The Journal of Political Economy, 95, 657-674.

Fligner, M. A. And G. E. Policello (1981): "Robust rank procedures for the Behrens-Fisher problem," Journal of the American Statistical Association, 76, 141206.

GrazzI, M. (2012): "Export and Firm Performance: Evidence on Productivity and Profitability of Italian Companies," Journal of Industry, Competition and Trade, 12, 413-444.

Grazzi, M., R. SAnzo, A. Secchi, And A. Zeli (2013): "The building process of a new integrated system of business micro-data 1989-2004," Journal of Economic and Social Measurement, 38, 291-324.

Grazzi, M. And C. Tomasi (2016): "Indirect exporters and importers," Review of World Economics (Weltwirtschaftliches Archiv), 152, 251-281.

Haltiwanger, J., R. S. Jarmin, And J. Miranda (2013): "Who Creates Jobs? Small versus Large versus Young," The Review of Economics and Statistics, 95, 347361.

Hsien, C.-T. And P. J. Klenow (2014): "The Life Cycle of Plants in India and Mexico," The Quarterly Journal of Economics, 1-50.

Huergo, E. And J. Jaumandreu (2004a): "Firms' age, process innovation and productivity growth," International Journal of Industrial Organization, 22, 541 - 559.

(2004b): "How Does Probability of Innovation Change with Firm Age?" Small Business Economics, 22, 193-207.

International Study Group on Exports And Productivity (2008): "Understanding Cross-Country Differences in Exporter Premia: Comparable Evidence for 14 Countries," Review of World Economics (Weltwirtschaftliches Archiv), 144, 596-635.

Jovanovic, B. (1982): "Selection and the Evolution of Industry," Econometrica, 50, 649-70.

Knight, G. A. And S. T. Cavusgil (2004): "Innovation, organizational capabilities, and the born-global firm," Journal of International Business Studies, 35, 124-141. 
Lawless, M. (2014): "Age or Size? Contributions to job creation," Small Business Economics, 42, 815-830.

Lotti, F., E. Santarelli, and M. Vivarelli (2003): "Does Gibrat's Law hold among young, small firms?" Journal of Evolutionary Economics, 13, 213-235.

Melitz, M. J. (2003): "The Impact of Trade on Intra-Industry Reallocations and Aggregate Industry Productivity," Econometrica, 71, 1695-1725.

Melitz, M. J. and G. I. P. Ottaviano (2008): "Market Size, Trade, and Productivity," Review of Economic Studies, 75, 295-316.

Neumark, D., B. Wall, and J. Zhang (2011): "Do Small Businesses Create More Jobs? New Evidence for the United States from the National Establishment Time Series," The Review of Economics and Statistics, 93, 16-29.

OECD (2012): Compendium of Productivity Indicators, OECD Publishing.

Roberts, M. J. And J. R. Tybout (1997): "The Decision to Export in Colombia: An Empirical Model of Entry with Sunk Costs," American Economic Review, 87, 545-64.

Serti, F. And C. Tomasi (2008): "Self-Selection and Post-Entry Effects of Exports: Evidence from Italian Manufacturing Firms," Review of World Economics (Weltwirtschaftliches Archiv), 144, 660-694.

Stanley, M., L. Amaral, S. Buldyrev, S. Havlin, H. Leschhorn, P. Maass, M. Salinger, And H. Stanley (1996): "Scaling behaviour in the growth of companies," Nature, 379, 804-806.

Sutton, J. (1997): "Gibrat's Legacy," Journal of Economic Literature, 35, 40-59.

Wagner, J. (2001): "A Note on the Firm Size - Export Relationship," Small Business Economics, 17, 229-237.

Zahra, S. A., R. D. Ireland, And M. A. Hitt (2000): "International Expansion by New Venture Firms: International Diversity, Mode of Market Entry, Technological Learning, and Performance," The Academy of Management Journal, 43, 925-950. 


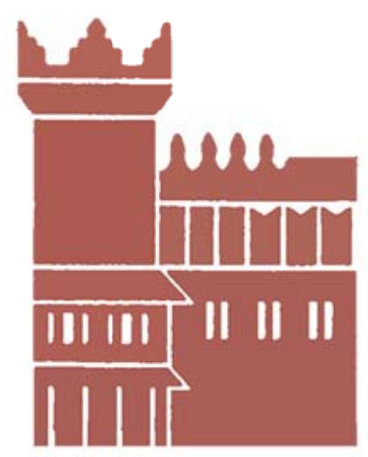

Alma Mater Studiorum - Università di Bologna DEPARTMENT OF ECONOMICS

Strada Maggiore 45

40125 Bologna - Italy

Tel. +39051 2092604

Fax +390512092664

http://www.dse.unibo.it 